\title{
Measurements of atmospheric ethene by solar absorption FTIR spectrometry
}

\author{
Geoffrey C. Toon, Jean-Francois L. Blavier, and Keeyoon Sung \\ Jet Propulsion Laboratory, California Institute of Technology, CA 91109, USA \\ Correspondence: Geoffrey C. Toon (geoffrey.c.toon@jpl.nasa.gov)
}

Received: 30 April 2017 - Discussion started: 8 June 2017

Revised: 28 December 2017 - Accepted: 2 January 2018 - Published: 16 April 2018

\begin{abstract}
Atmospheric ethene $\left(\mathrm{C}_{2} \mathrm{H}_{4}\right.$; ethylene) amounts have been retrieved from high-resolution solar absorption spectra measured by the Jet Propulsion Laboratory (JPL) MkIV interferometer. Data recorded from 1985 to 2016 from a dozen ground-based sites have been analyzed, mostly between 30 and $67^{\circ} \mathrm{N}$. At clean-air sites such as Alaska, Sweden, New Mexico, or the mountains of California, the ethene columns were always less than $1 \times 10^{15}$ molec $\mathrm{cm}^{-2}$ and therefore undetectable. In urban sites such as JPL, California, ethene was measurable with column amounts of $20 \times 10^{15} \mathrm{molec} \mathrm{cm}^{-2}$ observed in the 1990 s. Despite the increasing population and traffic in southern California, a factor 3 decrease in ethene column density is observed over JPL over the past 25 years, accompanied by a decrease in $\mathrm{CO}$. This is likely due to southern California's increasingly stringent vehicle exhaust regulations and tighter enforcement over this period.
\end{abstract}

Copyright statement. The author's copyright for this publication is transferred to the California Institute of Technology.

\section{Introduction}

Atmospheric ethene arises from microbial activity in soil and water, biological formation in plants, and by incomplete combustion from sources such as biomass burning, power plants, and combustion engines. Ethene is primarily destroyed by reaction with OH (Olivella and Sole, 2004), which is rapid, giving ethene a tropospheric lifetime of only 1 to 3 days. Despite covering only $29 \%$ of the Earth's area, the land produces $89 \%$ of the ethene (Sawada and
Totsuka, 1986). This is mainly natural, but in urban environments or near fires, ethene from incomplete combustion can dominate. Sawada and Totsuka (1986) used measurements of ethene emissions per unit biomass to derive a global source of $26.2 \mathrm{Tg} \mathrm{yr}^{-1}$ from natural emissions and $9.2 \mathrm{Tg} \mathrm{yr}^{-1}$ from anthropogenic emissions, giving a total of $35.4 \mathrm{Tg} \mathrm{yr}^{-1}$, which ranges from 18 to $45 \mathrm{Tg} \mathrm{yr}^{-1}$. Goldstein et al. (1996) measured ethene emissions from Harvard Forest, Massachusetts, and found that they were linearly correlated with levels of photosynthetically active radiation (PAR), indicating a photosynthetic source. Based on this, they estimated that at Harvard Forest biogenic emissions of ethene correspond to approximately $50 \%$ of anthropogenic sources. Using these fluxes, and the ecosystem areas tabulated by Sawada and Totsuka (1986), a global biogenic source for ethene of $21 \mathrm{Tg} \mathrm{yr}^{-1}$ was calculated. This value is similar to the estimates of Hough (1991). The ethene fluxes listed by Poisson et al. (2000), however, are only 11.8 $\mathrm{Tg} \mathrm{yr}^{-1}$, while those of Muller and Brasseur (1995) are only $5 \mathrm{Tg} \mathrm{yr}^{-1}$. Abeles et al. (1992) estimate a terrestrial biogenic source of $16.6 \mathrm{Tg} \mathrm{yr}^{-1}$ and an anthropogenic source of $9.2 \mathrm{Tg} \mathrm{yr}^{-1}$. Combustion of fossil fuels amounts to only $21 \%$ of these anthropogenic emissions globally, but in urban areas this can be the major source.

There have been previous measurements of ethene using in situ techniques and also using remote sensing. These will be discussed later in the context of comparisons with results from the Jet Propulsion Laboratory (JPL) MkIV interferometer, an infrared Fourier transform spectrometer that uses the sun as a source. We report here long-term remote sensing measurements of $\mathrm{C}_{2} \mathrm{H}_{4}$ in the lower troposphere, where the vast majority of $\mathrm{C}_{2} \mathrm{H}_{4}$ resides, using ground-based MkIV ob- 
servations. We also present MkIV balloon measurements of $\mathrm{C}_{2} \mathrm{H}_{4}$ in the upper troposphere.

\section{Methods}

\subsection{MkIV instrument}

The MkIV Fourier Transform Spectrometer (FTS) is a double-passed Fourier transform infrared (FTIR) spectrometer designed and built at the Jet Propulsion Laboratory (JPL) in 1984 for atmospheric observations (Toon, 1991). It covers the entire $650-5650 \mathrm{~cm}^{-1}$ region simultaneously with two detectors: a $\mathrm{HgCdTe}$ photoconductor covering $650-1800 \mathrm{~cm}^{-1}$ and an $\mathrm{InSb}$ photodiode covering 1800 $5650 \mathrm{~cm}^{-1}$. The MkIV instrument has flown 24 balloon flights since 1989. It has also flown on over 40 flights of the NASA DC-8 aircraft as part of various campaigns during 1987 to 1992 studying high-latitude ozone loss. MkIV has also made 1208 days of ground-based observations since 1985 from a dozen different sites, from Antarctica to the Arctic, from sea level to $3.8 \mathrm{~km}$ altitude. Details of the ground-based measurements and sites can be found at http://mark4sun.jpl.nasa.gov/ground.html. MkIV observations have been extensively compared with satellite remote sounders (e.g., Velazco et al., 2011) and with in situ data (e.g., Toon et al., 1999a, b).

\subsection{Spectral analysis}

The spectral fitting was performed with the GFIT (Gas Fitting) code, a nonlinear least-squares algorithm developed at JPL that scales the atmospheric gas volume mixing ratio (VMR) profiles to fit calculated spectra to those measured. For balloon observations, the atmosphere was discretized into 100 layers of $1 \mathrm{~km}$ thickness. For ground-based observations, 70 layers of $1 \mathrm{~km}$ thickness were used. Absorption coefficients were computed line-by-line assuming a Voigt line shape and using the ATM line list (Toon, 2014a) for the telluric lines. This is a "greatest hits" compilation, founded on HITRAN, but not always the latest version for every band of every gas. For example, in cases (gases/bands) where the HITRAN 2012 line list (Rothman et al., 2012) gave poorer fits than HITRAN 2008, the earlier version was retained. The $\mathrm{C}_{2} \mathrm{H}_{4}$ line list covering the $950 \mathrm{~cm}^{-1}$ region containing the $\nu_{7}$ and $v_{8}$ bands is described by Rothman et al. (2003). The solar line list (Toon, 2014b) used in the analysis of the groundbased MkIV spectra was obtained from balloon flights of the MkIV instrument.

Sen et al. (1996) provide a more detailed description of the use of the GFIT code for retrieval of VMR profiles from MkIV balloon spectra. GFIT was previously used for the Version 3 analysis (Irion et al., 2003) of spectra measured by the Atmospheric Trace Molecule Occultation Spectrometer (ATMOS), and it is currently used for analysis of Total Car- bon Column Observing Network (TCCON) spectra (Wunch et al., 2011) and MkIV spectra (Toon, 2016).

We analyzed the strongest infrared absorption feature of ethene: the Q-branch of the $v_{7}$ band $\left(\mathrm{CH}_{2}\right.$ wag $)$ at $949 \mathrm{~cm}^{-1}$. This is 7 times stronger than any other feature, including the $3000 \mathrm{~cm}^{-1}$ region containing the $\mathrm{CH}$-stretch vibrational modes.

For data acquisition from JPL, the MkIV instrument was indoors with a coelostat mounted to the south wall of the building feeding direct sunlight into the room. Figure 1 shows a fit to the $943-957 \mathrm{~cm}^{-1}$ region of one such spectrum. The strongest absorptions are from $\mathrm{H}_{2} \mathrm{O}$ lines (orange), one of which is blacked out at $948.25 \mathrm{~cm}^{-1}$. There are also eight $\mathrm{CO}_{2}$ lines (amber) in this window with depths of $40-60 \%$, one of which sits directly atop the $\mathrm{C}_{2} \mathrm{H}_{4}$ Qbranch at $949.35 \mathrm{~cm}^{-1}$. These $\mathrm{CO}_{2}$ lines are temperaturesensitive, having ground-state energies in the range 1400 to $1600 \mathrm{~cm}^{-1}$. It is not possible to clearly see the $\mathrm{C}_{2} \mathrm{H}_{4}$ absorption in Fig. 1, and so Fig. 2 zooms into the Q-branch region. The lower panel reveals that the peak $\mathrm{C}_{2} \mathrm{H}_{4}$ absorption is less than $1 \%$ deep and strongly overlapped by $\mathrm{CO}_{2}$. It is also overlapped by absorption from $\mathrm{H}_{2} \mathrm{O}, \mathrm{SF}_{6}, \mathrm{NH}_{3}$, $\mathrm{N}_{2} \mathrm{O}$, and solar $\mathrm{OH}$ lines. $\mathrm{NH}_{3}$ absorption lines exceed $1 \%$ in this window on this particular day but do not overlap the strongest part of the $\mathrm{C}_{2} \mathrm{H}_{4}$ Q-branch. The $\mathrm{SF}_{6} \nu_{3} \mathrm{Q}$-branch at $947.9 \mathrm{~cm}^{-1}$ also exceeds $1 \%$ but fortunately does not overlap the $\mathrm{C}_{2} \mathrm{H}_{4} \mathrm{Q}$-branch. The $\mathrm{SF}_{6} \mathrm{R}$-branch, however, underlies the $\mathrm{C}_{2} \mathrm{H}_{4}$ Q-branch with about $0.3 \%$ absorption depth. The upper panel shows the same spectrum fitted without any $\mathrm{C}_{2} \mathrm{H}_{4}$ absorption. This causes a $\sim 0.5 \%$ dip in the residuals around $949.35 \mathrm{~cm}^{-1}$ and an increase in the overall $\mathrm{rms}$ from 0.234 to $0.251 \%$. The $0.5 \%$ dip in the residuals is weaker than the $0.9 \%$ depth of the $\mathrm{C}_{2} \mathrm{H}_{4}$ feature in the lower panel because the other fitted gases have been adjusted to try to compensate for the missing $\mathrm{C}_{2} \mathrm{H}_{4}$. Their inability to completely do so supports the attribution of this dip to $\mathrm{C}_{2} \mathrm{H}_{4}$.

Given the severity of the interference, especially the directly overlying $60 \%$ deep $\mathrm{CO}_{2}$ line, we were at first skeptical that $\mathrm{C}_{2} \mathrm{H}_{4}$ could be retrieved to a worthwhile accuracy from this window, or any other. But given the good quality of the spectral fits, and the small reported uncertainties, we nevertheless went ahead and analyzed the entire MkIV groundbased spectral dataset, consisting of 4379 spectra acquired on 1208 different days over the past 30 years. Of these 1208 days, 1132 were used in this work.

Figure 3 shows the averaging kernel and a priori profile pertaining to the $\mathrm{C}_{2} \mathrm{H}_{4}$ retrieval illustrated in Figs. 1 and 2 . The kernel represents the change in the total retrieved column due to the addition of one unit of $\mathrm{C}_{2} \mathrm{H}_{4}$ molecules $\mathrm{cm}^{-2}$ at a particular altitude. In a perfect column retrieval, the kernel would be 1.0 at all altitudes, but in reality the retrieval is more sensitive to $\mathrm{C}_{2} \mathrm{H}_{4}$ at high altitudes than near the surface, as is typical for a profile-scaling retrieval of a weakly absorbing gas. The a priori VMR profile has a value of $500 \mathrm{ppt}$ at the surface, dropping rapidly to $10 \mathrm{ppt}$ by $5 \mathrm{~km}$ altitude. An even 


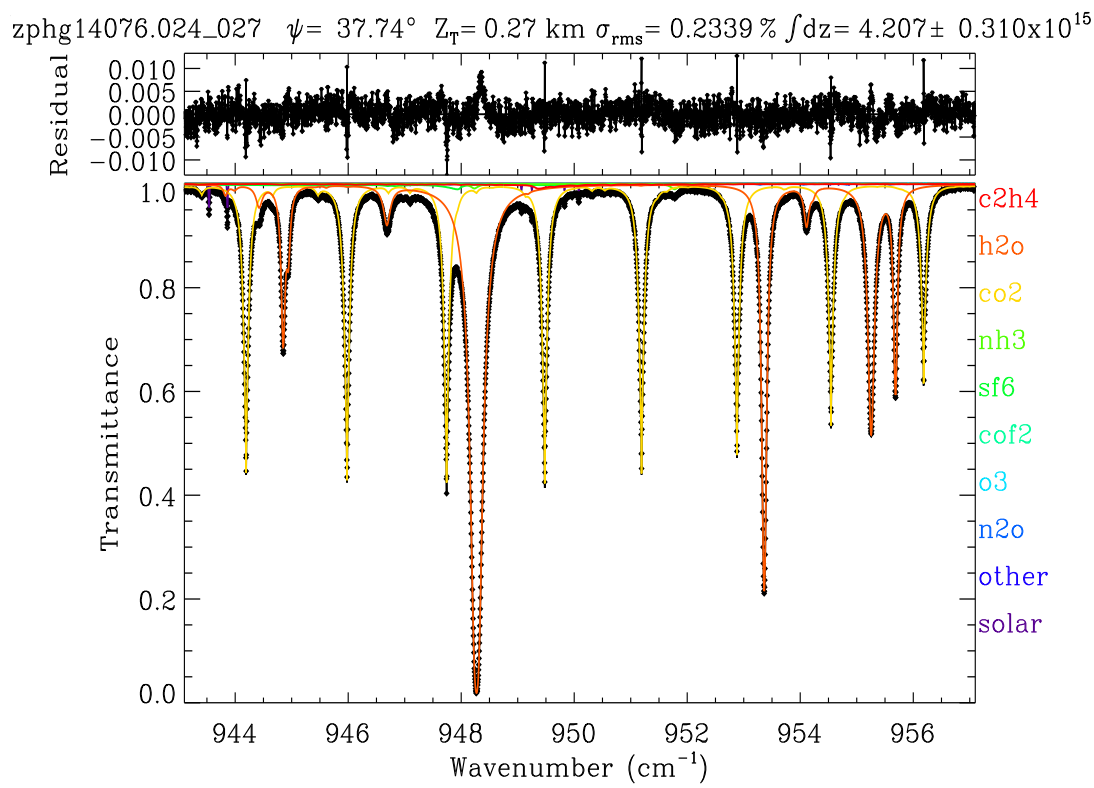

Figure 1. Example of a fit to a ground-based MkIV spectrum measured from JPL, California, on 17 March 2014 at a solar zenith angle of $\psi=37.7^{\circ}$ from a pressure altitude of $Z_{T}=0.27 \mathrm{~km}$. In the lower panel, black diamond symbols represent the measured spectrum, the black line represents the fitted calculation, and the colored lines represent the contributions of the various absorbing gases, mainly $\mathrm{CO}_{2}$ (amber) and $\mathrm{H}_{2} \mathrm{O}$ (orange). Also fitted are the 0 and $100 \%$ signal levels, separate telluric and solar frequency shifts, together with five more weakly absorbing gases $\left(\mathrm{NH}_{3}, \mathrm{SF}_{6}, \mathrm{COF}_{2}, \mathrm{O}_{3}\right.$, and $\left.\mathrm{N}_{2} \mathrm{O}\right)$. The retrieved $\mathrm{C}_{2} \mathrm{H}_{4}$ column amount on this day, $4.2 \times 10^{15}$ molec $\mathrm{cm}^{-2}$, would represent $2 \mathrm{ppb}$ confined to the lowest $100 \mathrm{mbar}(1.5 \mathrm{~km})$ of the atmosphere. The $\mathrm{C}_{2} \mathrm{H}_{4}$ absorption contribution (red) peaks at $949.35 \mathrm{~cm}^{-1}$ with an amplitude of less than $1 \%$ and is therefore difficult to discern on this plot. The upper panel shows fitting residuals (measured minus calculated), peaking at $0.013(1.3 \%)$ with an rms deviation of $0.234 \%$, which are mainly correlated with absorption features of $\mathrm{H}_{2} \mathrm{O}$ and $\mathrm{CO}_{2}$.

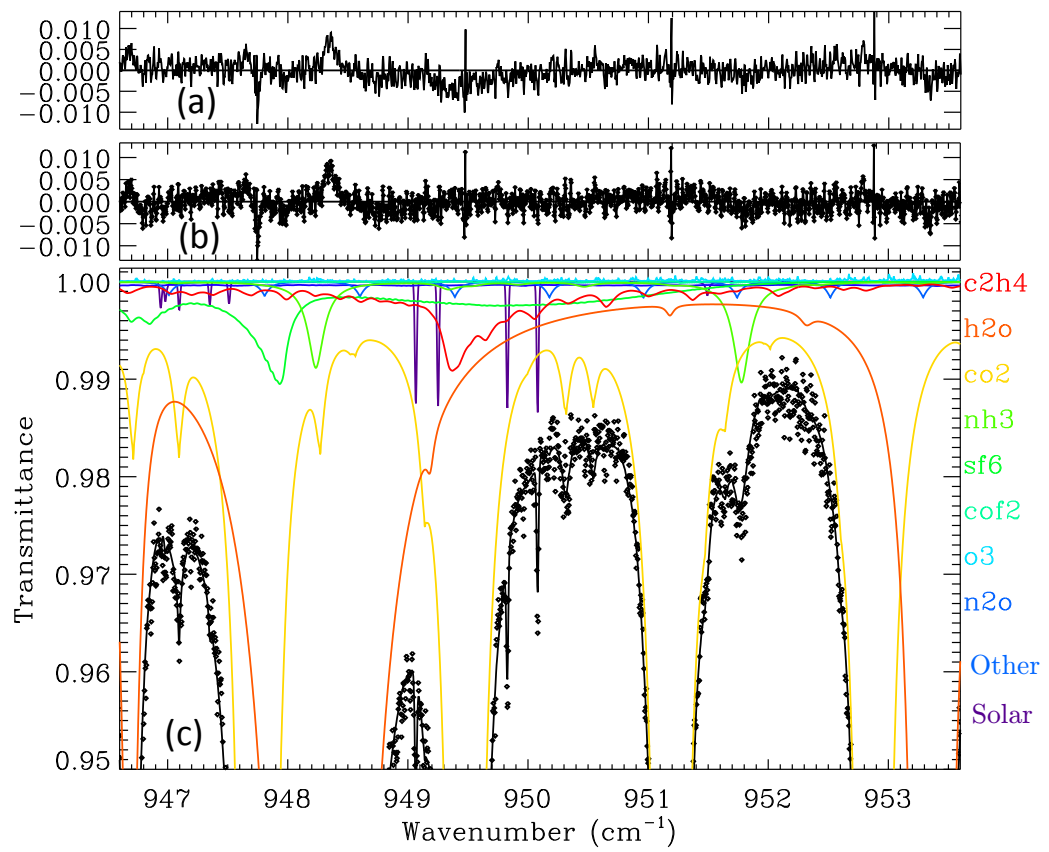

Figure 2. Panels (b) and (c) are as described in Fig. 1, but zoomed in to reveal more detail of the $\mathrm{C}_{2} \mathrm{H}_{4}$ Q-branch (red) whose absorption peaks at $949.35 \mathrm{~cm}^{-1}$. Panel (a) shows residuals from a fit that omitted $\mathrm{C}_{2} \mathrm{H}_{4}$. This causes a discernable $0.5 \%$ dip in the residuals around $949.35 \mathrm{~cm}^{-1}$ and a worsening of the rms spectral fits from 0.234 to $0.251 \%$. 

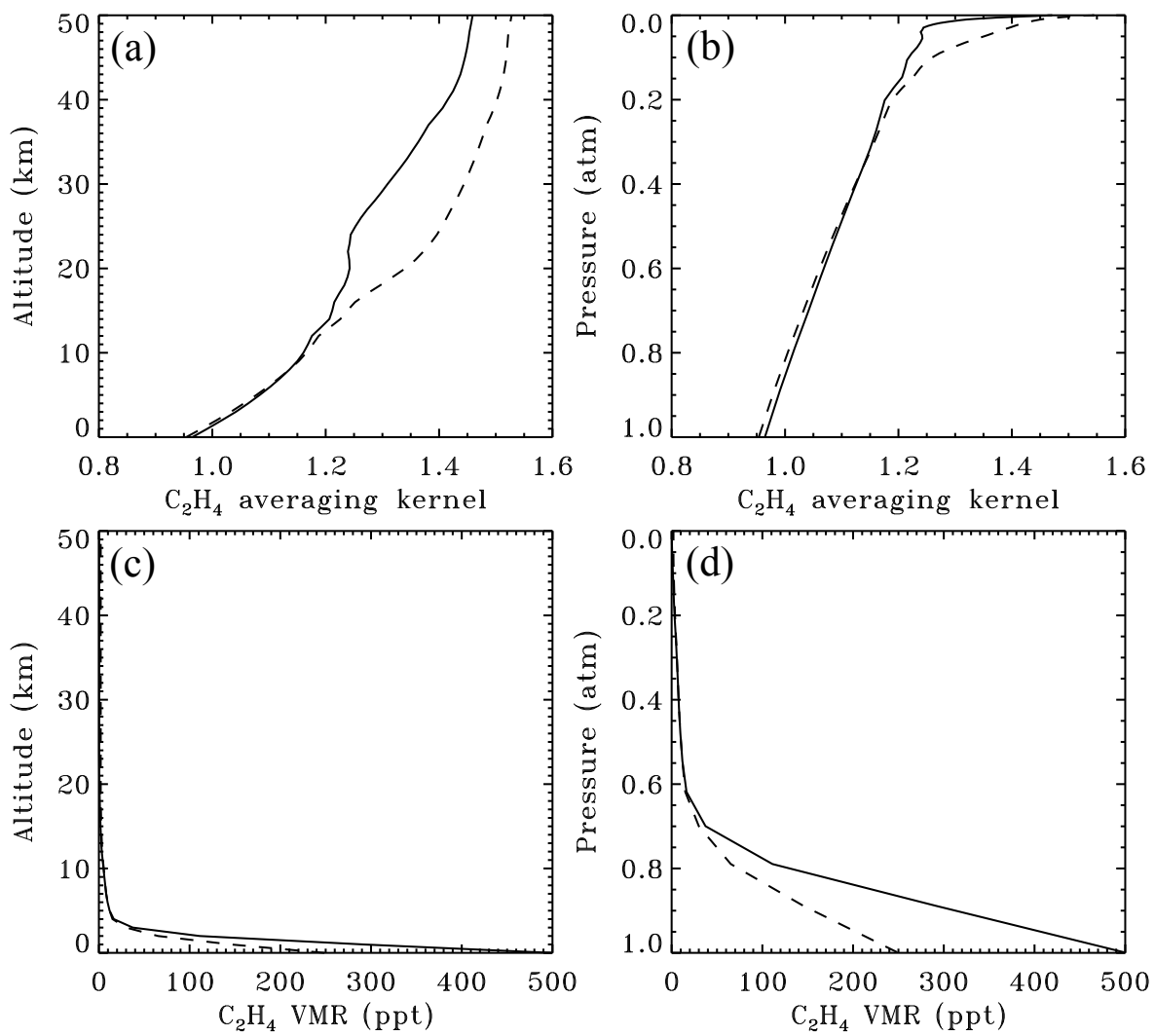

Figure 3. Averaging kernels (a, b) and a priori volume mixing ratio (VMR) profiles (c, d) pertaining to the ground-based $\mathrm{C}_{2} \mathrm{H}_{4}$ retrieval illustrated in Figs. 1 and 2. In panels (a) and (c) quantities are plotted versus altitude. Panels (b, d) show the same data plotted versus atmospheric pressure. The solid line is the actual profile used. The dashed line is a VMR profile with a less dramatic decrease with altitude: the $\mathrm{C}_{2} \mathrm{H}_{4}$ VMR below $4 \mathrm{~km}$ has been halved, with similar amounts in the upper troposphere, and more in the stratosphere. The resulting change in the retrieved total column is only $2 \%$, with the dashed profile giving the smaller columns.

larger fractional drop, from 10 to $0.5 \mathrm{ppt}$ occurs in the lower stratosphere between 15 and $21 \mathrm{~km}$. The slight kink in the averaging kernel (solid line) over this same altitude range is due to this large drop in VMR. Since $99 \%$ of the $\mathrm{C}_{2} \mathrm{H}_{4}$ lies in the troposphere, the stratospheric portion of the averaging kernel is of academic interest only for total column retrievals.

An important uncertainty in the retrieved column amounts is likely to be the smoothing error, which represents the effect of error in the shape of the a priori VMR profile. If the averaging kernel were perfect (i.e., 1.0 at all altitudes) this would not matter, but in fact the $\mathrm{C}_{2} \mathrm{H}_{4}$ kernels vary from 0.96 at the ground to 1.4 at $40 \mathrm{~km}$ altitude. To investigate the sensitivity of the retrieved column to the assumed a priori profile, we also performed retrievals with a different a priori VMR profile in which the $\mathrm{C}_{2} \mathrm{H}_{4}$ VMR profile had been halved in the $0-4 \mathrm{~km}$ altitude range and increased in the stratosphere, as depicted by the dashed line in Fig. 3. The resulting change in the retrieved $\mathrm{C}_{2} \mathrm{H}_{4}$ column was less than $2 \%$ with no discernable change to the rms fitting residuals, which are dominated by the interfering gases. This small $\mathrm{C}_{2} \mathrm{H}_{4}$ column perturbation is a result of the averaging kernel being close to 1.0 at the altitudes with the largest a priori VMR errors $(0-3 \mathrm{~km})$. Note that only errors in the shape of the a priori VMR profile affect the retrieved columns in a profile scaling retrieval.

\section{Results}

\subsection{Ground-based MkIV retrievals}

Figure 4 shows the retrieved MkIV ground-based $\mathrm{C}_{2} \mathrm{H}_{4}$ columns from a dozen different observation sites, whose key attributes (e.g., latitude, longitude, altitude, observations, observation days) are presented in Tables SI.1 and SI.2 in the Supplement. The plot is color-coded by the pressure altitude of the site. This was preferred over geometric altitude to prevent all the points from a given site piling up at exactly the same $x$-value. The pressure altitude varies by up to $\pm 1.5 \%$ at the high altitude sites, which is equivalent to $\pm 0.2 \mathrm{~km}$. Only points with $\mathrm{C}_{2} \mathrm{H}_{4}$ uncertainties $<1 \times 10^{15}$ molecules $\mathrm{cm}^{-2}$ were included in the plot, representing $95.7 \%$ of the total data volume. One day (out of 258 ) at Barcroft (3.8 km altitude) was omitted from the plotted data because it had abnor- 

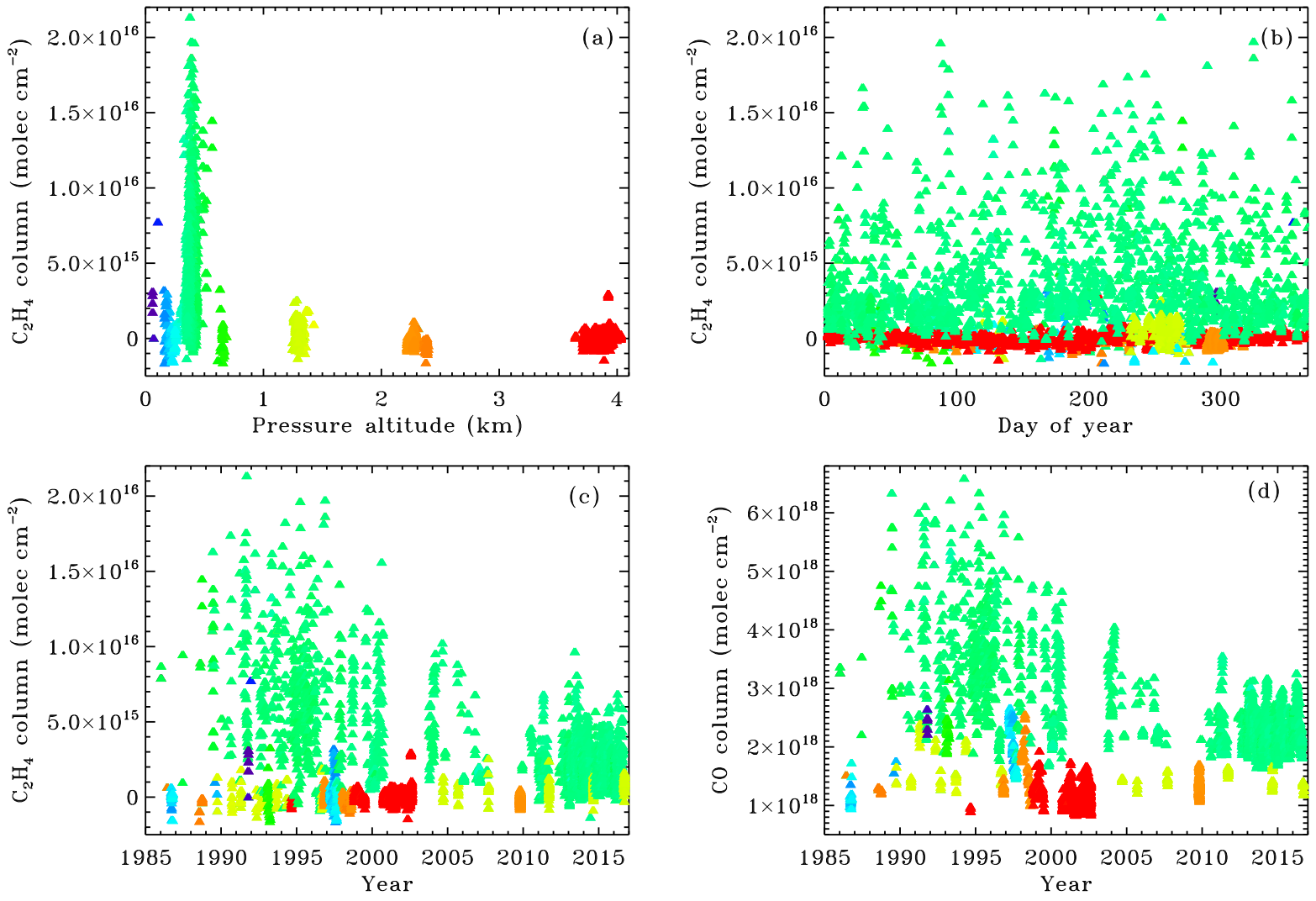

Figure 4. MkIV column $\mathrm{C}_{2} \mathrm{H}_{4}$ amounts retrieved from 12 different sites, color-coded by pressure altitude. Significant $\mathrm{C}_{2} \mathrm{H}_{4}$ amounts are only found at the urban sites: JPL at $0.35 \mathrm{~km}$ altitude (green) and Mountain View at $0.01 \mathrm{~km}$ altitude (purple). Panel (b) reveals little seasonal variation in $\mathrm{C}_{2} \mathrm{H}_{4}$. Panel (c) shows a factor 3 decline in $\mathrm{C}_{2} \mathrm{H}_{4}$ in Pasadena over the past 25 years. Panel (d) shows that the CO columns also decreased since 1990, but never come close to zero.

mally high $\mathrm{C}_{2} \mathrm{H}_{4}$, as well as other short-lived gases - clearly a local pollution event.

At all sites above $0.5 \mathrm{~km}$ altitude there is essentially no measurable $\mathrm{C}_{2} \mathrm{H}_{4}$. The Table Mountain Facility (TMF) site at $2.3 \mathrm{~km}$ altitude (orange) is only $25 \mathrm{~km}$ from the most polluted part of the Los Angeles basin; yet no measurable $\mathrm{C}_{2} \mathrm{H}_{4}$ was recorded there in 45 observation days, despite the good measurement accuracy at this site (see Fig. SI.3 in the Supplement). This is probably a result of the TMF always being above the PBL (planetary boundary layer), in which urban pollution is trapped, at least on the autumn and winter days when MkIV made measurements at the TMF. The highlatitude sites at Fairbanks, Esrange, and McMurdo also have no measurable $\mathrm{C}_{2} \mathrm{H}_{4}$, as do rural, midlatitude sites (e.g., Ft. Sumner, NM). The only sites where MkIV has ever detected $\mathrm{C}_{2} \mathrm{H}_{4}$ are JPL/Pasadena $(0.4 \mathrm{~km}$; green) and Mountain View $(0.01 \mathrm{~km}$, purple). These sites are part of major conurbations: Pasadena adjoins Los Angeles; Mountain View adjoins San Jose, California.

The main limitation to the accuracy of $\mathrm{C}_{2} \mathrm{H}_{4}$ measurements using the solar absorption technique is the ability to accurately account for the absorption from $\mathrm{CO}_{2}, \mathrm{H}_{2} \mathrm{O}$, and $\mathrm{SF}_{6}$, which overlap the Q-branch. The first two gases, in particular, being much stronger absorbers than $\mathrm{C}_{2} \mathrm{H}_{4}$, have the potential to drastically perturb the $\mathrm{C}_{2} \mathrm{H}_{4}$ retrieval. For example, an error in the assumed $\mathrm{H}_{2} \mathrm{O}$ VMR vertical profile, and hence the shape of the $\mathrm{H}_{2} \mathrm{O}$ absorption line, will have a large effect on retrieved $\mathrm{C}_{2} \mathrm{H}_{4}$. And since the overlapping $\mathrm{CO}_{2}$ lines are so temperature-sensitive $\left(\sim 2 \% \mathrm{~K}^{-1}\right)$, a small error in the assumed tropospheric temperature would greatly influence the $\mathrm{C}_{2} \mathrm{H}_{4}$ retrieval. Errors in the spectroscopy of $\mathrm{H}_{2} \mathrm{O}$ and $\mathrm{CO}_{2}$ will also strongly affect $\mathrm{C}_{2} \mathrm{H}_{4}$ retrievals. Figure SI.3 shows the $\mathrm{C}_{2} \mathrm{H}_{4}$ retrieval uncertainties, estimated by solving the matrix equation that relates the Jacobians of the various retrieved quantities to the spectral residuals. The uncertainties are the square root of the diagonal elements of the resulting covariance matrix. The same data are plotted versus year, solar zenith angle, and site altitude. From JPL the measurement uncertainty is about $0.5 \times 10^{15}$ molec $\mathrm{cm}^{-2}$. At higher solar zenith angles (air masses) the uncertainty decreases as the $\mathrm{C}_{2} \mathrm{H}_{4}$ absorption deepens. At higher altitudes the uncertainty decreases as the interfering absorptions shrink faster than that of $\mathrm{C}_{2} \mathrm{H}_{4}$. There has been no significant change in the $\mathrm{C}_{2} \mathrm{H}_{4}$ retrieval uncertainty over the 30 -year measurement pe- 

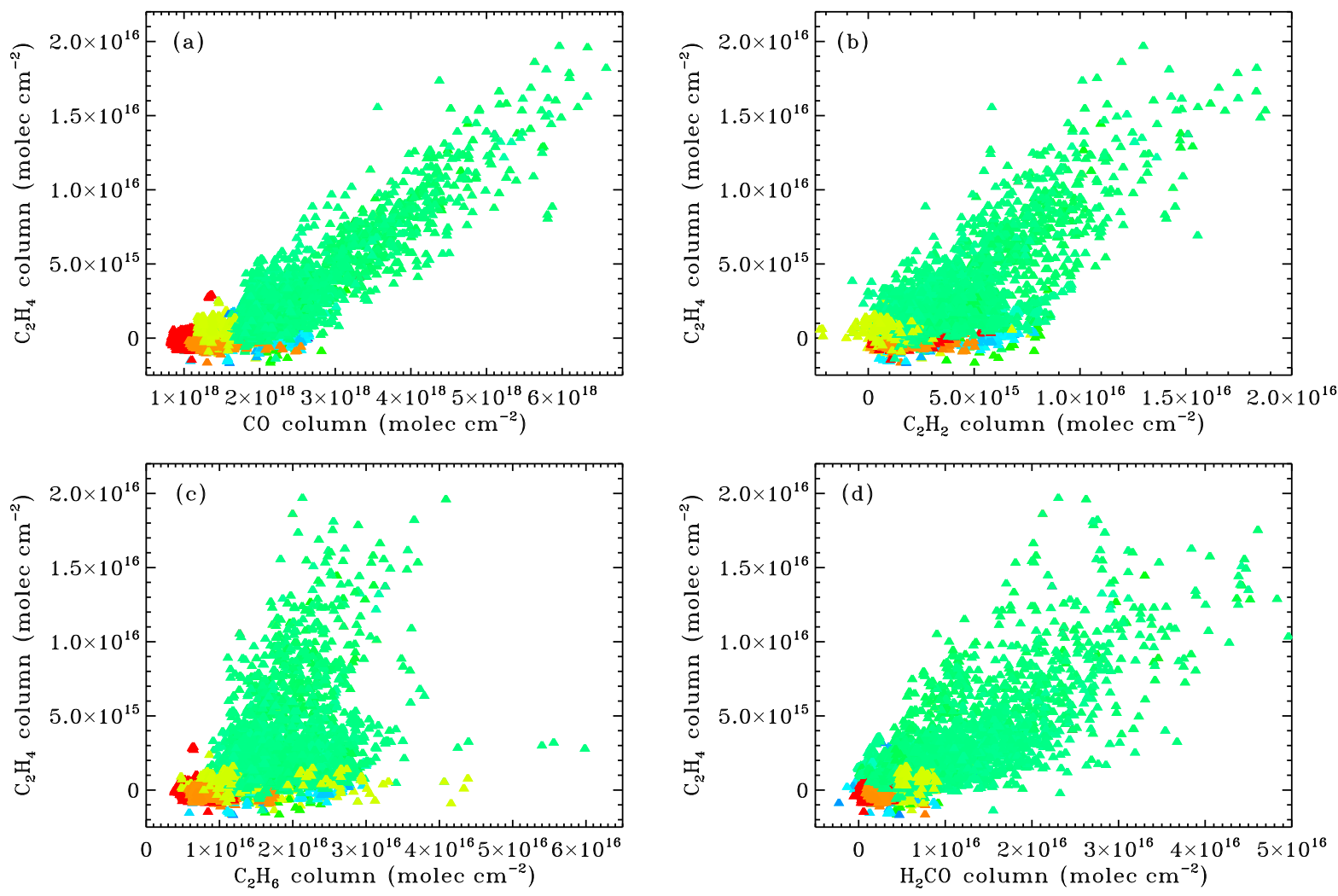

Figure 5. Relationships between $\mathrm{C}_{2} \mathrm{H}_{4}$ and four other gases: (a) $\mathrm{CO}$, (b) $\mathrm{C}_{2} \mathrm{H}_{2}$, (c) $\mathrm{C}_{2} \mathrm{H}_{6}$, and (d) $\mathrm{H}_{2} \mathrm{CO}$. Points are color-coded by altitude, as in Fig. 4.

riod. We note that the measurements made from McMurdo, Antarctica, in September/October 1986 have very small uncertainties, due to their high air mass and the extremely small $\mathrm{H}_{2} \mathrm{O}$ absorption. The plotted uncertainties represent a single observation representing a $10-15 \mathrm{~min}$ integration period. A total of $95.7 \%$ of the $\mathrm{C}_{2} \mathrm{H}_{4}$ observations have uncertainties $<1.0 \times 10^{15}$ molec cm $^{-2}$.

At JPL the $\mathrm{C}_{2} \mathrm{H}_{4}$ column is highly variable. JPL is located at the northern edge of the Los Angeles conurbation, and so when winds are from the northern sector, or strong from the ocean, pollution levels are much smaller than during stagnant conditions. This is seen in the large range of retrieved $\mathrm{C}_{2} \mathrm{H}_{4}$ values observed at JPL throughout the year. A notable feature of the MkIV $\mathrm{C}_{2} \mathrm{H}_{4}$ data (Fig. 4c) is the factor 3 drop over the past 25 years. In the $1990 \mathrm{~s}_{2} \mathrm{H}_{4}$ often topped $16 \times 10^{15}$ molec $\mathrm{cm}^{-2}$, but since 2010 a column exceeding $8 \times 10^{15}$ has only been observed once.

Figure $4 \mathrm{~d}$ shows the $\mathrm{CO}$ time series, which exhibits a substantial decline since the 1990s, although not as dramatic as that of $\mathrm{C}_{2} \mathrm{H}_{4}$ since $\mathrm{CO}$ never falls below $1.5 \times 10^{18}$ molec cm$^{-2}$ at JPL, even under the cleanest conditions, due to its nonzero background concentration.

Figure 5 shows the relationships between $\mathrm{C}_{2} \mathrm{H}_{4}$ and four other gases: $\mathrm{CO}, \mathrm{C}_{2} \mathrm{H}_{2}, \mathrm{C}_{2} \mathrm{H}_{6}$, and $\mathrm{H}_{2} \mathrm{CO}$. Figure 5 a reveals a compact, linear relationship between $\mathrm{C}_{2} \mathrm{H}_{4}$ and $\mathrm{CO}$ at JPL (green points), suggesting a common local source for both. Figure $5 b-d$ show that $\mathrm{C}_{2} \mathrm{H}_{4}$ is clearly related to the other gases, but not as strongly as with $\mathrm{CO}$. This is likely due to them having other sources; for example, $\mathrm{C}_{2} \mathrm{H}_{6}$ also comes from natural gas leaks, causing the bifurcated appearance of Fig. 5c. Since these trace gases are much less abundant than $\mathrm{CO}$, their measurements are noisier, which also degrades the compactness of the relationship.

Figure 6 plots the gas column relationships for the JPL data only, color-coded by year to help reveal the long-term changes. The decreases in the $\mathrm{CO}, \mathrm{C}_{2} \mathrm{H}_{2}, \mathrm{C}_{2} \mathrm{H}_{4}$, and $\mathrm{H}_{2} \mathrm{CO}$ since the 1990s are evident by the lack of red points in the upper right of the panels plotting these gases. $\mathrm{C}_{2} \mathrm{H}_{6}$ has not decreased significantly as is evident from the third row of panels, which shows that the 2015 column abundances (red) span similar values to those measured in 1990 (blue). In fact, on 10 November 2015, we observed a factor 2-3 enhancement of the $\mathrm{C}_{2} \mathrm{H}_{6}$ column as a result of JPL being directly downwind of the Aliso Canyon natural gas leak on that day (Conley et al., 2016). Although this event was associated with a $2.5 \%$ enhancement of column $\mathrm{CH}_{4}$ (not shown here), there were no enhancements of $\mathrm{CO}, \mathrm{C}_{2} \mathrm{H}_{2}, \mathrm{C}_{2} \mathrm{H}_{4}$, so these particular $\mathrm{C}_{2} \mathrm{H}_{6}$ points (red) in the third row of Fig. 6 protrude upwards from the main clusters. Since $\mathrm{C}_{2} \mathrm{H}_{6}$ has failed to decrease over the measurement period, unlike the other gases, 

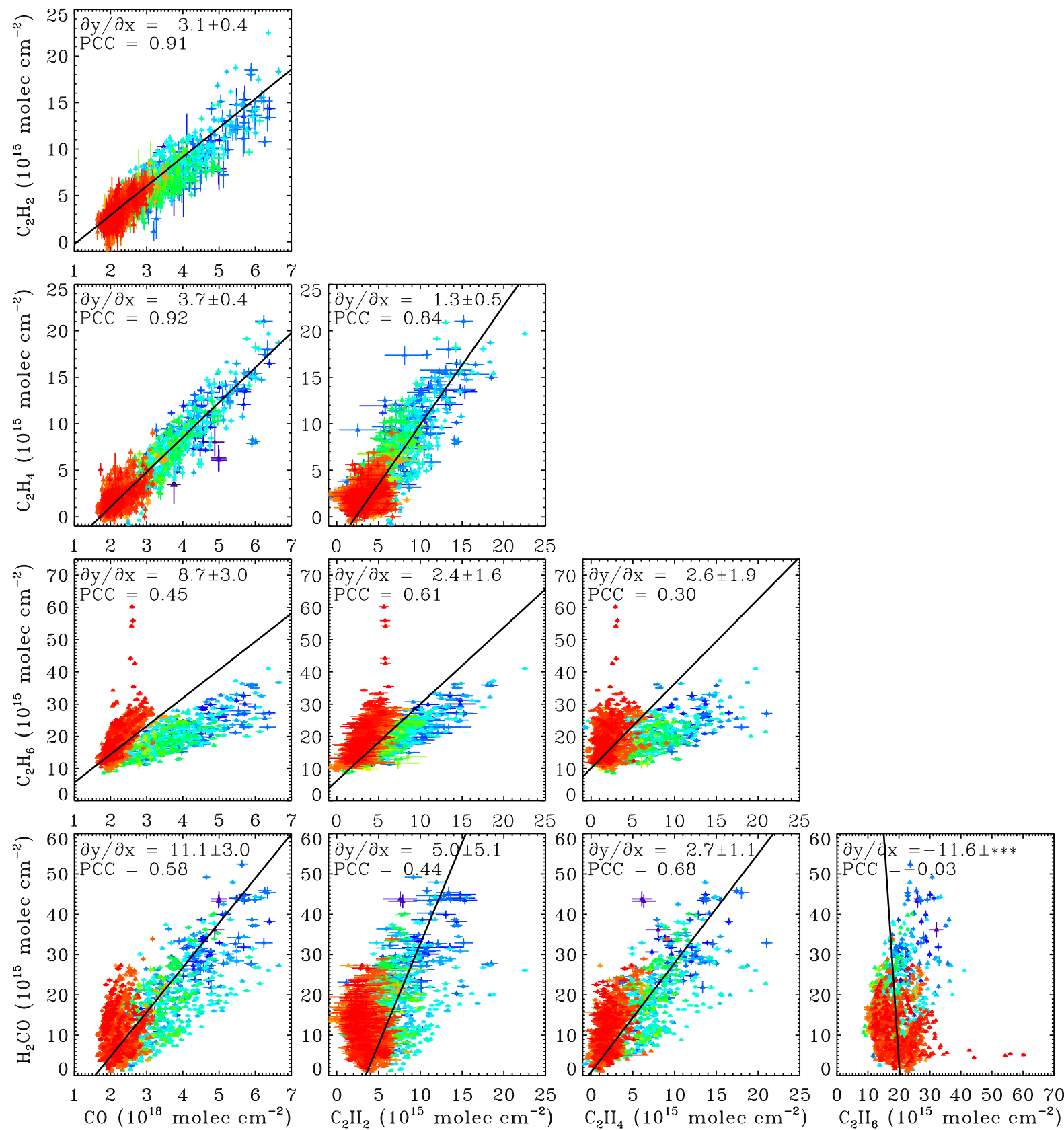

Figure 6. Relationships between MkIV vertical column abundances of various gases measured from JPL only, color-coded by year (blue is 1990, green is 2000, orange is 2010, and red is 2015). The black line in each panel is the best-fit straight line through the data (not constrained to pass through the origin). The gradient of the fitted straight line $(\partial y / \partial x)$ and the Pearson correlation coefficient (PCC) are written at the top of each panel. Panels on the same row all have the same $y$ axis, avoiding repetition of the $y$ annotation. Panels in the same column have the same $x$ axis, avoiding repetition of the $x$ annotation. Each panel contains 1689 to 1724 observations, representing over $98 \%$ of the available JPL data. Note that the CO abundances have been divided by 1000 to bring them closer to the other gases. Thus the gas : CO gradients are in units of ppt $\mathrm{ppb}^{-1}$, whereas the gradients of the non-CO gases are in ppt $\mathrm{ppt}^{-1}$. In the first column, the gradients could be termed "emission ratios". 
the $\mathrm{C}_{2} \mathrm{H}_{6}$-gas relationships all show a bifurcation, with the later data (red) showing steeper gradients (more $\mathrm{C}_{2} \mathrm{H}_{6}$ ).

A straight line was fitted through the data in each panel of Fig. 6, allowing a gradient and an offset to be computed. The values of the gradients $(\partial y / \partial x)$ are written into each panel, along with their uncertainties. The overall gradient of the $\mathrm{C}_{2} \mathrm{H}_{4} / \mathrm{CO}$ relationship using all JPL data is $3.7 \pm 0.4 \mathrm{ppt} \mathrm{ppb}^{-1}$, but the post-2010 JPL data have a gradient of only $2.8 \pm 0.4 \mathrm{ppt} \mathrm{ppb}^{-1}$. Baker et al. (2008) measured $\mathrm{C}_{2} \mathrm{H}_{4} / \mathrm{CO}$ emission ratios of $5.7 \mathrm{ppt} \mathrm{ppb}^{-1}$ in Los Angeles from whole air canister samples acquired between 1999 and 2005, which is close to their average of all US cities, $4.1 \mathrm{ppt} \mathrm{ppb}^{-1}$. Over this same time period the MkIV JPL data report $3.9 \pm 0.7 \mathrm{ppt}^{\mathrm{ppb}} \mathrm{p}^{-1}$, the larger uncertainty reflecting the relatively few observations from JPL over this period. Warneke et al. (2007) report a $\mathrm{C}_{2} \mathrm{H}_{4} / \mathrm{CO}$ emissions ratio of $4.9 \mathrm{ppt} \mathrm{ppb}^{-1}$ in Los Angeles in 2002, measured by aircraft canister samples. Warneke et al. (2012) report decreases of 6-8 \% $\mathrm{yr}^{-1}$ in $\mathrm{C}_{2} \mathrm{H}_{4}$ and $\mathrm{CO}$ over Los Angeles between 2002 and 2010, but little change in the $\mathrm{C}_{2} \mathrm{H}_{4} / \mathrm{CO}$ emission ratio, which remained at 5-6 ppt $\mathrm{ppb}^{-1}$.

Figure 6 also includes the Pearson correlation coefficients (PCCs) of the JPL-only gas relationships. The highest values are between $\mathrm{CO}$ and $\mathrm{C}_{2} \mathrm{H}_{2}(0.91)$ and $\mathrm{CO}$ and $\mathrm{C}_{2} \mathrm{H}_{4}(0.92)$. The PCC between $\mathrm{C}_{2} \mathrm{H}_{2}$ and $\mathrm{C}_{2} \mathrm{H}_{4}$ is only 0.84 , probably reflecting the fact that $\mathrm{C}_{2} \mathrm{H}_{2}$ and $\mathrm{C}_{2} \mathrm{H}_{4}$ are much more difficult to measure (i.e., noisier) than $\mathrm{CO}$. The worst correlation is between $\mathrm{C}_{2} \mathrm{H}_{6}$ and $\mathrm{H}_{2} \mathrm{CO}(-0.03)$.

To see whether the ground-based MkIV $\mathrm{C}_{2} \mathrm{H}_{4}$ measured in Pasadena was correlated with the air mass origin, we performed HYSPLIT back trajectories, and computed the amount of time that air masses arriving $500 \mathrm{~m}$ above JPL had spent over the highly populated areas of the Los Angeles conurbation. When column $\mathrm{C}_{2} \mathrm{H}_{4}$ was plotted versus the predicted duration over the conurbation, the correlation was very poor. Column $\mathrm{CO}$ also had a poor correlation. The fact that the $\mathrm{C}_{2} \mathrm{H}_{4}$ correlates well with $\mathrm{CO}$ tends to discount the possibility that the $\mathrm{C}_{2} \mathrm{H}_{4}$ measurements are wrong, since the $\mathrm{CO}$ measurements are very easy. Therefore, this implies that the trajectories are not sufficiently accurate. We point out that JPL is located at the foot of the San Gabriel mountains, which rise over $1 \mathrm{~km}$ above JPL over a horizontal distance of less than $5 \mathrm{~km}$. This extreme topography might give rise to complexities in the wind fields that might be inadequately represented in the EDAS $40 \mathrm{~km}$ resolution model. Although higher resolution models (e.g., NAM $12 \mathrm{~km}$ ) are available for doing HYSPLIT trajectories, these cover only the past decade, whereas the JPL MkIV measurements go back more than 30 years.

\subsection{MkIV balloon profiles}

We also looked for ethene in MkIV balloon spectra using exactly the same window, spectroscopy, and fitting software (GFIT) as used for MkIV ground-based measurements. The advantage of the balloon spectra is that the air mass is much larger and the solar and instrumental features are removed from the occultation spectra by ratioing them against a highSun spectrum taken at noon from float altitude.

Figure 7 shows a spectral fit to the MkIV balloon spectrum at $6.1 \mathrm{~km}$ tangent altitude measured above Esrange, Sweden, in December 1999. The peak $\mathrm{C}_{2} \mathrm{H}_{4}$ absorption at $949.35 \mathrm{~cm}^{-1}$ is about $6 \%$ deep, although this falls beneath a saturated $\mathrm{CO}_{2}$ line. The information about $\mathrm{C}_{2} \mathrm{H}_{4}$ at this and lower altitudes therefore comes from adjacent weaker features. At higher altitudes (not shown), where the $\mathrm{CO}_{2}$ lines are weaker and narrower, the $\mathrm{C}_{2} \mathrm{H}_{4}$ information comes mainly from the $949.35 \mathrm{~cm}^{-1} \mathrm{Q}$-branch.

Figure 8 shows 30 balloon profiles of $\mathrm{C}_{2} \mathrm{H}_{4}$ from 23 flights, color-coded according to date. The $\mathrm{C}_{2} \mathrm{H}_{4}$ VMR retrieved from the December 1999 flight (green) was $65 \pm 6 \mathrm{ppt}$ at $6 \mathrm{~km}$, decreasing to $14 \pm 4$ at $7 \mathrm{~km}$, and undetectable above. The remaining balloon flights indicate a $10 \mathrm{ppt}$ upper limit for $\mathrm{C}_{2} \mathrm{H}_{4}$ in the free troposphere and $15 \mathrm{ppt}$ in the stratosphere. Of course, these balloon flights were generally launched under calm, anticyclonic, clear-sky conditions, which tend to preclude transport of PBL pollutants up to the free troposphere. Therefore, there may be an inherent sampling bias in the MkIV balloon measurements that leads to low $\mathrm{C}_{2} \mathrm{H}_{4}$.

PBL altitudes $(0-3 \mathrm{~km})$ are inaccessible from balloon flights due to the high aerosol content making the long limb path opaque (although they can be probed from the ground). Therefore, the balloon measurements are not inconsistent with $\mathrm{C}_{2} \mathrm{H}_{4}$ existing in measurable quantities in the polluted PBL, as implied by ground-based measurements. The typical 1-3 day lifetime of $\mathrm{C}_{2} \mathrm{H}_{4}$ at midlatitudes and low latitudes implies that it will only be measurable in the free troposphere soon after rapid uplift.

\subsection{Comparison with remote sensing measurements}

Paton-Walsh et al. (2005) measured up to $300 \times 10^{15}$ molec cm $^{-2}$ of $\mathrm{C}_{2} \mathrm{H}_{4}$ during fire events in southeast (SE) Australia in 2001-2003 with aerosol optical depths of up to 5.5 at $500 \mathrm{~nm}$ wavelength. From spectra acquired during one of the most intense of these fires (1 January 2002), Rinsland et al. (2005) retrieved a total $\mathrm{C}_{2} \mathrm{H}_{4}$ column of $380 \pm 20 \times 10^{15}$ through a dense smoke plume and inferred a huge mole fraction of $37 \mathrm{ppb}$ peaking at about $1 \mathrm{~km}$ above ground level. This retrieval used information from the shape of the Q-branch feature, which was nearly as deep as the overlapping $\mathrm{CO}_{2}$ line. These $\mathrm{C}_{2} \mathrm{H}_{4}$ amounts are 20 times larger than anything seen by MkIV, even from polluted JPL.

Coheur et al. (2007) reported a $\mathrm{C}_{2} \mathrm{H}_{4}$ VMR of $70 \pm 20 \mathrm{ppt}$ at $11.5 \mathrm{~km}$ altitude in a biomass burning plume, observed by the Atmospheric Chemistry Experiment (ACE) (Bernath et al., 2005) off the east coast of Africa. They also show measured $\mathrm{C}_{2} \mathrm{H}_{4}$ exceeding $100 \mathrm{ppt}$ below $8 \mathrm{~km}$. Simultane- 


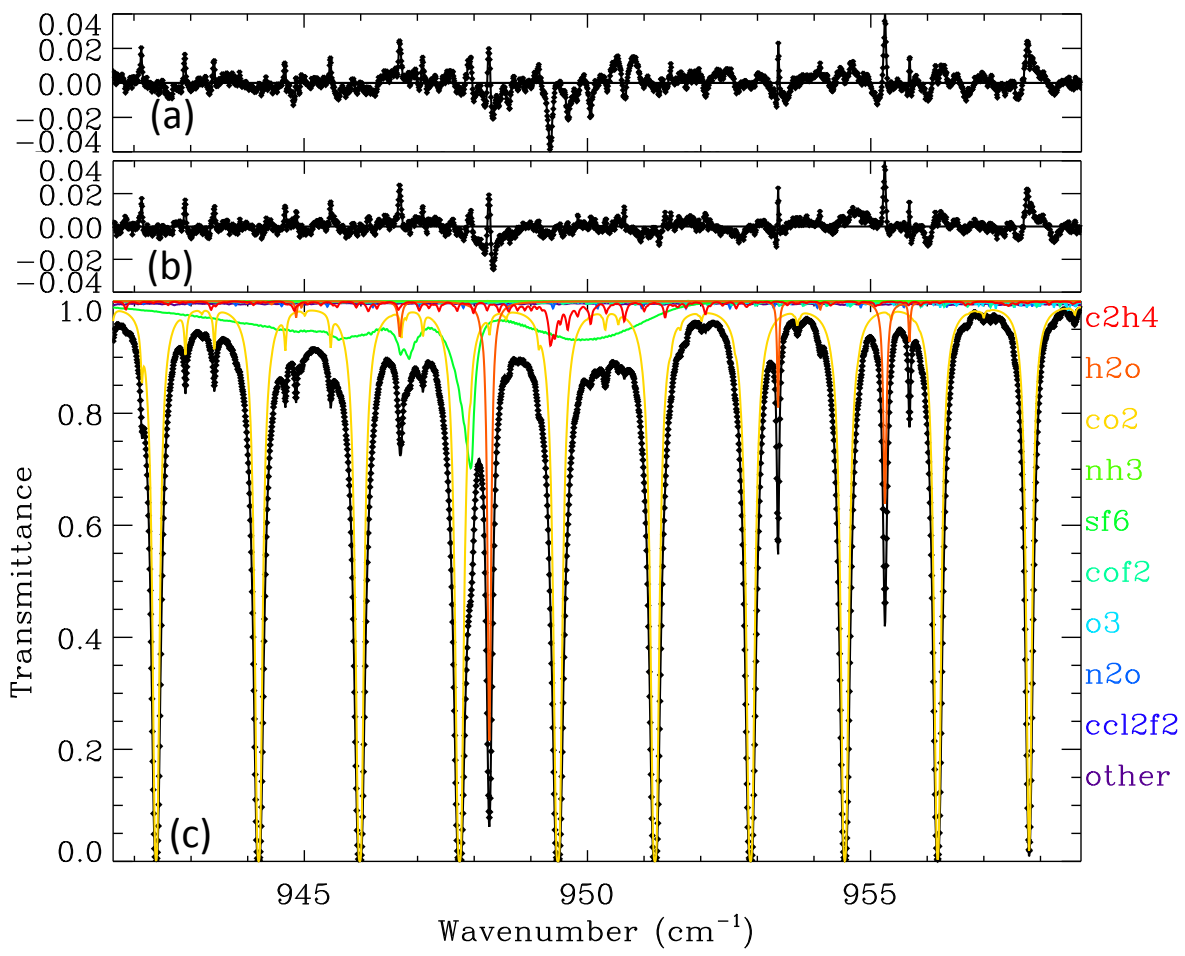

Figure 7. Panel (c) shows a fit to a MkIV balloon spectrum measured over Esrange, Sweden, in December 1999, with strong $\mathrm{C}_{2} \mathrm{H}_{4}$ absorption measured at $6.1 \mathrm{~km}$ tangent altitude. The $\mathrm{C}_{2} \mathrm{H}_{4}$ absorption is denoted by the red line. Its Q-branch is seen at $949.35 \mathrm{~cm}^{-1}$, reaching $6 \%$ in depth in this particular spectrum. In addition to $\mathrm{C}_{2} \mathrm{H}_{4}$, other gases were adjusted including $\mathrm{H}_{2} \mathrm{O}, \mathrm{CO}_{2}, \mathrm{O}_{3}, \mathrm{SF}_{6}, \mathrm{COF}_{2}, \mathrm{~N}_{2} \mathrm{O}, \mathrm{NH}_{3}$, and $\mathrm{CCl}_{2} \mathrm{~F}_{2} \cdot \mathrm{CH}_{3} \mathrm{OH}$ was included in the calculation but not adjusted. Panel (b) shows residuals (measured minus calculated), the largest values of which are mainly due to $\mathrm{H}_{2} \mathrm{O}$. Panel (a) shows residuals after omitting $\mathrm{C}_{2} \mathrm{H}_{4}$ from the calculation, which causes a large dip in the residuals at $949.35 \mathrm{~cm}^{-1}$ and increases the overall $\mathrm{rms}$ residual from 0.50 to $0.63 \%$.

ous measurement of elevated $\mathrm{C}_{2} \mathrm{H}_{2}, \mathrm{CO}, \mathrm{C}_{2} \mathrm{H}_{6}, \mathrm{HCN}$, and $\mathrm{HNO}_{3}$ confirm their biomass burning hypothesis.

Herbin et al. (2009) reported zonal average ethene profiles above $6 \mathrm{~km}$ altitude based on global measurements by ACE. Figure 2 of Herbin et al. (2009) shows $35^{\circ} \mathrm{N}$ zonal average VMRs of $40 \mathrm{ppt}$ at $6 \mathrm{~km}$ altitude, $30 \mathrm{ppt}$ at $8 \mathrm{~km}$, and $15 \mathrm{ppt}$ at $14 \mathrm{~km}$ altitude, with error bars as small as 1 ppt. Herbin et al. (2009) also wrote to following: "We find that a value of $20 \mathrm{ppt}$ is close to the detection threshold at all altitudes in the troposphere". To reconcile these two statements we assume that the 20 ppt detection limit refers to a single occultation, whereas the 1 ppt error bar is the result of co-adding hundreds of ACE profiles.

Herbin et al. (2009) also report increasing $\mathrm{C}_{2} \mathrm{H}_{4}$ with latitude. Although the ACE zonal means agree with the in situ measurements made during the PEM-West and TRACE-P, these campaigns were designed to measure the outflow of Asian pollution and therefore sampled some of the worst pollution on the planet. Therefore, one would expect lower values in a zonal average. Based on the total absence of negative values in any of their retrieved VMR profiles, we believe that Herbin et al. performed a $\log (\mathrm{VMR})$ retrieval, imposing an implicit positivity constraint. This would have led to a noise-dependent, high bias in their retrieved profiles in places where $\mathrm{C}_{2} \mathrm{H}_{4}$ was undetectable.

Clerbeaux et al. (2009) reported $\mathrm{C}_{2} \mathrm{H}_{4}$ column abundances reaching $3 \times 10^{15} \mathrm{molec} \mathrm{cm}^{-2}$ from spectra acquired by the IASI satellite instrument, a nadir-viewing emission sounder. This isolated event occurred in May 2008 over East Asia and was associated with a Siberian fire plume, as confirmed by back trajectories and co-located enhancements of $\mathrm{CH}_{3} \mathrm{OH}$, $\mathrm{HCOOH}$, and $\mathrm{NH}_{3}$.

More recently, $\mathrm{C}_{2} \mathrm{H}_{4}$ was detected in boreal fire plumes (Alvarado et al., 2011; Dolan et al., 2016) during the 2008 ARCTAS mission by the Tropospheric Emission Spectrometer (TES), a nadir-viewing thermal emission FTS on board the Aura satellite. A strong correlation with $\mathrm{CO}$ was observed. TES's $\mathrm{C}_{2} \mathrm{H}_{4}$ sensitivity depends strongly on the thermal contrast: the temperature of the $\mathrm{C}_{2} \mathrm{H}_{4}$ relative to that of the underlying surface. For plumes in the free troposphere a detection limit of $2-3 \mathrm{ppb}$ is claimed from a single sounding with a $5 \times 8 \mathrm{~km}$ footprint.

\subsection{Comparison with in situ measurements}

There are a lot of published in situ ethene measurements. Here we intend to discuss only those that are in some way 


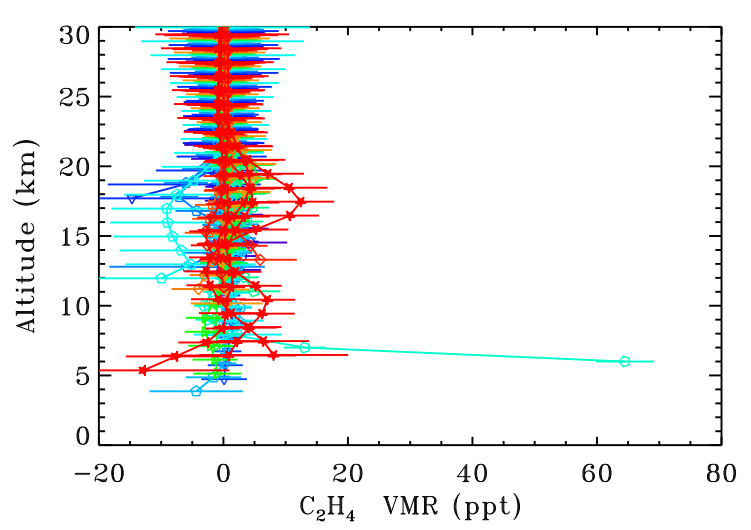

Figure 8. MkIV $\mathrm{C}_{2} \mathrm{H}_{4}$ profiles from 24 balloon flights color-coded by year (purple is 1989, green is 2000, and red is 2014). Altitude offsets of up to $0.4 \mathrm{~km}$ have been applied for clarity, to prevent the error bars from over-writing each other at each integer altitude. In only one flight, launched in December 1999 from Esrange, Sweden, was a significant amount of $\mathrm{C}_{2} \mathrm{H}_{4}$ measured (green points at 6-7 km altitude). In other flights there was no detection, with upper limits varying from 10 to $15 \mathrm{ppt}$. The increase in uncertainty with altitude above $10 \mathrm{~km}$ is due to the $\mathrm{C}_{2} \mathrm{H}_{4}$ absorption feature weakening in comparison with the spectral noise. Below $10 \mathrm{~km}$ the increasing uncertainty is due to the greater interference by $\mathrm{H}_{2} \mathrm{O}$ and $\mathrm{CO}_{2}$. Note that the negative $\mathrm{C}_{2} \mathrm{H}_{4}$ values are all associated with large uncertainties.

comparable with MkIV measurements. These include measurements over the western United States and profiles over the Pacific Ocean in the $30-40^{\circ} \mathrm{N}$ latitude range that are upwind of MkIV balloon measurements. Other measurements, e.g., over Europe and mainland SE Asia, are less relevant, given the 1-3 day lifetime of $\mathrm{C}_{2} \mathrm{H}_{4}$.

Gaffney et al. (2012) reported surface $\mathrm{C}_{2} \mathrm{H}_{4}$ over Texas and neighboring states measured in 2002. They reported a median VMR of $112 \mathrm{ppt}$, with occasionally much larger values of up to $2 \mathrm{ppb}$, presumably when downwind of local sources. This median value, if present only within a PBL that is 150 mbar thick, represents a total column of $0.3 \times 10^{15} \mathrm{molec} \mathrm{cm}^{-2}$, which would be undetectable in ground-based MkIV measurements, consistent with the nondetection of $\mathrm{C}_{2} \mathrm{H}_{4}$ from Ft. Sumner, New Mexico (1.2 km).

Lewis et al. (2013) reported airborne in situ measurements of non-methane organic compounds over SE Canada in summer 2010. The median ethene VMR was $49 \mathrm{ppt}$, with plumes averaging 1848 ppt. Their $\mathrm{C}_{2} \mathrm{H}_{4} / \mathrm{CO}$ scatter plot (Fig. $2 \mathrm{~b}$ of Lewis et al., 2013) reveals two distinct branches. Biomass burning plumes show an emission ratio of $6.97 \mathrm{ppt} \mathrm{ppb}^{-1}$, whereas local/anthropogenic emissions show an emission ratio of about $1.3 \mathrm{ppt} \mathrm{ppb}^{-1}$. These values bracket the MkIV value of $3.7 \pm 0.4 \mathrm{ppt} \mathrm{ppb}^{-1}$ obtained from the green points in Fig. 5a and all points of Fig. 6 of the current paper.

Blake et al. (2003) report mean $\mathrm{C}_{2} \mathrm{H}_{4}$ profiles from 0 to $12 \mathrm{~km}$ during the February-April 2001 TRACE-P aircraft campaign, during which aircraft based in Hong Kong and

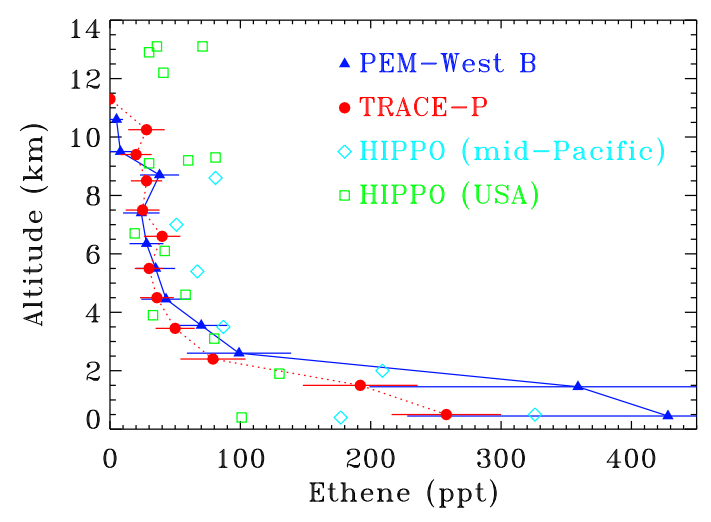

Figure 9. Aircraft in situ measurements of ethene. HIPPO measurements of $\mathrm{C}_{2} \mathrm{H}_{4}$ made by the Advanced Whole Air Sampler between 30 and $40^{\circ} \mathrm{N}$ are shown by cyan diamonds (mid-Pacific) and green squares (central United States). Also shown are PEM-West B (blue triangles) and TRACE-P (red circles) measurements of $\mathrm{C}_{2} \mathrm{H}_{4}$ over coastal SE Asia and the western Pacific (taken from Fig. 9 of Blake et al., 2003).

Tokyo sampled outflow from SE Asia. Blake et al. (2003) compared these results with those from the similar 1991 and 1994 PEM-West campaigns. Figure 11 in Blake et al. shows that below $2 \mathrm{~km}, \mathrm{C}_{2} \mathrm{H}_{4}$ averaged 100 ppt during TRACE-P and 250 ppt during PEM-West. Blake et al.'s Table 1 provides a median $\mathrm{C}_{2} \mathrm{H}_{4}$ of $30 \mathrm{ppt}$ at $35^{\circ} \mathrm{N}$ at $2-8 \mathrm{~km}$ altitude in the western Pacific for both TRACE-P and PEM-West. Below $2 \mathrm{~km}$ the VMRs were much larger, especially during PEMWest. Blake et al.'s Fig. 9 shows mean PBL VMRs of 200 ppt during TRACE-P and 400 ppt during PEM-West, rapidly decreasing to $50 \mathrm{ppt}$ by $4 \mathrm{~km}$ altitude, $30 \mathrm{ppt}$ by $6 \mathrm{~km}$, and less than 20 ppt above $9 \mathrm{~km}$. Blake et al.'s Fig. 2 shows high $\mathrm{C}_{2} \mathrm{H}_{4}$ in the coastal margins of China, decreasing rapidly by a few hundred kilometers off shore, consistent with the short $\mathrm{C}_{2} \mathrm{H}_{4}$ lifetime. Since these aircraft campaigns were designed to measure polluted outflow from East Asia, the most polluted region on the planet, their samples cannot be considered representative of a zonal average. Over the mid-Pacific, $\mathrm{C}_{2} \mathrm{H}_{4}$ amounts were $0-15$ ppt at all altitudes during TRACE-P and PEM-West B.

Sather and Cavender (2016) reported surface in situ measurements of ozone and volatile organic compounds (including ethene) from the cities of Dallas-Ft. Worth, Houston, El Paso, Texas, and from Baton Rouge, Louisiana, over the past 30 years. For ethene the measurements span the late 1990 s to 2015 , but nevertheless show clear declines by factors of 2-4 during 05:00-08:00 on weekdays. The authors attribute this decrease to the impacts of the 1990 amendment to the US Clean Air Act.

Ethene was measured during the HIAPER Pole-to-Pole (HIPPO; Wofsy et al., 2011, 2012) mission by the Advanced Whole Air Sampler. Figure 9 plots the $\mathrm{C}_{2} \mathrm{H}_{4}$ VMRs measured in the $30-40^{\circ} \mathrm{N}$ latitude range. Points are color-coded 
by longitude. The cyan points were measured in the midPacific in January and December 2009, April 2010, and June and July 2011. The green points were measured over the central and western United States in January and December 2009, and June and July 2011. Profiles from the PEMWest B and TRACE-C aircraft campaigns are plotted in red and blue. Surprisingly, $\mathrm{C}_{2} \mathrm{H}_{4}$ is larger over the mid-Pacific (blue/purple points) than the United States (red points) at altitudes below $9 \mathrm{~km}$. This is presumably due to Asian pollution being further destroyed while crossing the eastern $\mathrm{Pa}$ cific. Above $9 \mathrm{~km}$ the $\mathrm{C}_{2} \mathrm{H}_{4}$ is larger over the United States, presumably due to upward transport of the Asian pollution.

Washenfelder et al. (2011) performed ground-based in situ measurements from Pasadena, California, of several glyoxal precursors in early June 2010, as part of the CalNEX 2010 campaign. An ethene mole fraction of $2.16 \mathrm{ppb}$ was reported. Assuming that this value was present throughout the PBL, extending from the surface at 1000 mbar to the $900 \mathrm{mbar}$ level, then the in situ measurement implies a total $\mathrm{C}_{2} \mathrm{H}_{4}$ column of $4 \times 10^{15}$ molec $\mathrm{cm}^{-2}$, which is consistent with the upper range of values observed by MkIV in 2010. Unfortunately we do not have temporally overlapping measurements, and even if we did, JPL is $10 \mathrm{~km}$ away from the Pasadena site.

Washenfelder et al. (2011) also report a factor 6 drop in $\mathrm{C}_{2} \mathrm{H}_{4}$ amounts since the September 1993 CalNEX campaign, but note that the 1993 readings occurred during a smog episode, implying levels of pollution higher than normal. This drop is larger than the factor 3 decrease seen in the MkIV column data, but not inconsistent given the sparse statistics together with the large day-to-day variability seen in the MkIV data.

Measurements of ethene from ground level in Mexico City in 1999, 2002, and 2003 ranged between 10 and 60 ppb, with higher levels in the commercial sectors and lower values in residential areas (Altuzar et al., 2001, 2005; Velasco et al., 2007). These are 5-30 times larger than the $2.16 \mathrm{ppb}$ measured by Washenfelder et al. (2011) in Pasadena in 2010.

\section{Discussion}

The simultaneous reductions in $\mathrm{CO}$ and $\mathrm{C}_{2} \mathrm{H}_{4}$ groundbased column amounts measured from JPL over the past 25 years, and their continued high correlation, suggest a common source: vehicle exhaust. The declines in $\mathrm{CO}$ and $\mathrm{C}_{2} \mathrm{H}_{4}$ are likely a result of improved vehicle emission control systems, mandated by the increasingly stringent requirements imposed by the US Environmental Protection Agency (EPA; e.g., the 1990 Clean Air Act), various state laws, and the California Air Resources Board (CARB, LEV2) over the past decades and stronger enforcement thereof (e.g., smog checks). This view is supported by Bishop and Stedman (2008) who showed that vehicle emissions of hydrocarbons in several US cities including Los Angeles have steadily decreased with vehicle model year since 1986 .
$\mathrm{C}_{2} \mathrm{H}_{4} / \mathrm{CO}$ emission ratios measured over JPL by MkIV have decreased over the 30 year record, from $3.7 \pm 0.4 \mathrm{ppt} \mathrm{ppb}^{-1}$ overall to $2.7 \pm 0.4 \mathrm{ppt} \mathrm{ppb}^{-1}$ in recent years. It is not clear what is causing this decrease since many things have changed that might affect $\mathrm{C}_{2} \mathrm{H}_{4}$ levels (e.g., regulation of internal combustion engine exhaust, elimination of oil-based paints and lighter fuel, better control of emissions from oil and gas wells).

MkIV balloon measurements have only detected ethene once in 24 flights: in the Arctic in December 1999 at altitudes below $6 \mathrm{~km}$. In all other flights an upper limit of $15 \mathrm{ppt}$ was established for the free troposphere and $10 \mathrm{ppt}$ for the lower stratosphere. These upper limits are substantially smaller than the ACE $35^{\circ} \mathrm{N}$ zonal mean profiles reported by Herbin et al. (2009), which are possibly biased high when $\mathrm{C}_{2} \mathrm{H}_{4}$ amounts are small due to a positivity constraint imposed on the retrievals. Also, a single biomass burning plume with up to $25 \mathrm{ppb}$ of $\mathrm{C}_{2} \mathrm{H}_{4}$ has the potential to significantly increase the zonal mean $\mathrm{C}_{2} \mathrm{H}_{4}$. For this reason, a zonal median would be a more robust statistic. It is also possible that the MkIV balloon flights underrepresent conditions in which PBL pollution is lofted due to their location and the meteorology associated with balloon launches. Herbin et al. (2009) reported an increase of the $6 \mathrm{~km} \mathrm{ACE} \mathrm{C}_{2} \mathrm{H}_{4}$ with latitude in the Northern Hemisphere, peaking at 53 ppt at $70^{\circ} \mathrm{N}$. This is consistent with the December $1999 \mathrm{MkIV}$ balloon flight from $67^{\circ} \mathrm{N}$, which measured $60 \mathrm{ppt}$ at $6 \mathrm{~km}$.

MkIV balloon measurements over the western United States reveal much smaller ethene amounts than in situ aircraft measurements over SE Asia during TRACE-P, PEMWest $\mathrm{B}$, and over the mid-Pacific Ocean during HIPPO. With its 1-3-day lifetime, $\mathrm{C}_{2} \mathrm{H}_{4}$ decreases substantially during its eastward journey across the Pacific, which would help reconcile the in situ measurements with the MkIV balloon profiles.

\section{Summary and conclusions}

A 30-year record of atmospheric $\mathrm{C}_{2} \mathrm{H}_{4}$ has been extracted from ground-based FTIR spectra measured by the JPL MkIV instrument. Despite its high sensitivity, MkIV only detects ethene at polluted urban sites (e.g., Pasadena, California). At clean sites visited by $\mathrm{MkIV}, \mathrm{C}_{2} \mathrm{H}_{4}$ was undetectable (less than $10^{15}$ molec $\mathrm{cm}^{-2}$ ). MkIV ground-based measurements are generally consistent with the available surface in situ measurements, although a definitive comparison is difficult due to the large variability of $\mathrm{C}_{2} \mathrm{H}_{4}$ and lack of coincidence.

A large decline in $\mathrm{C}_{2} \mathrm{H}_{4}$ has been observed over Pasadena over the past 25 years. This is likely the result of increasingly stringent requirements on vehicle emissions imposed by the US Environmental Protection Agency (e.g., the 1990 Clean Air Act) and the California Air Resources Board (LowEmission Vehicle 2 requirements) over the past decades, together with stronger enforcement of these regulations (e.g., 
smog checks). The $\mathrm{C}_{2} \mathrm{H}_{4} / \mathrm{CO}$ emissions ratio also appears to have decreased in recent years.

This work shows that $\mathrm{C}_{2} \mathrm{H}_{4}$ might in future become a routine product of the Network for the Detection of Atmospheric Composition Change (NDACC) infrared FTS network, at least at sites near large sources. Moreover, since the spectra are saved, a historical $\mathrm{C}_{2} \mathrm{H}_{4}$ record may be retro-actively extractable at some of the more polluted sites.

Data availability. MkIV balloon profiles used in this study can be accessed from https://mark4sun.jpl.nasa.gov/m4data.html. MkIV ground-based column data used in this study can be accessed from http://mark4sun.jpl.nasa.gov/ground.html. These were last updated by the lead author (Geoffrey C. Toon) in 2017.

Supplement. The supplement related to this article is available online at: https://doi.org/10.5194/acp-18-5075-2018-supplement.

Competing interests. The authors declare that they have no conflict of interest.

Special issue statement. This article is part of the special issue "Twenty-five years of operations of the Network for the Detection of Atmospheric Composition Change (NDACC) (AMT/ACP/ESSD inter-journal SI)". It is not associated with a conference.

Acknowledgements. This research was performed at the Jet Propulsion Laboratory, California Institute of Technology, under contract with the National Aeronautics and Space Administration. We thank the Columbia Scientific Balloon Facility (CSBF) who conducted the majority of the balloon flights. We also thank the CNES Balloon Launch facility who conducted two MkIV balloon flights from Esrange, Sweden. We thank the Swedish Space Corporation for their support and our use of their facilities. We thank the HIAPER Pole-to-Pole Observations (HIPPO) campaign for use of their data. Finally, we acknowledge support from the NASA Upper Atmosphere Research Program. California Institute of Technology. Government sponsorship is acknowledged.

Edited by: Neil Harris

Reviewed by: two anonymous referees

\section{References}

Abeles, F. B., Morgan, P. W., and Saltveit Jr., M. E.: Ethylene in Plant Biology, 2nd Edn., 414 pp., ISBN: 978-0-08-091628-6, 1992.

Altuzar, V., Pacheco, M., Tomas, S. A., Arriaga, J. L., ZelayaAngel, O., and Sanchez Sinencio, F.: Analysis of ethylene concentration in the Mexico City atmosphere by photoacoustic spectroscopy, Anal. Sci., 17, 541-543, 2001.
Altuzar, V., Tomás, S. A., Zelaya-Angel, O., Sánchez-Sinencio, F., and Arriaga, J. L.: Atmospheric ethene concentrations in Mexico City: indications of strong diurnal and seasonal dependences, Atmos. Environ., 39, 5215-5225, 2005.

Alvarado, M. J., Cady-Pereria, K. E., Xiao, Y., Millet, D. B., and Payne, V. H.: Emission ratios for ammonia and formic acid and observations of peroxy acetyl nitrate (PAN) and ethylene in biomass burning smoke as seen by the tropospheric emission spectrometer (TES), Atmosphere, 2, 633-644, https://doi.org/10.3390/atmos2040633, 2011.

Baker, A. K., Beyersdorf, A. J., Doezema, L. A., Katzenstein, A., Meinardi, S., Simpson, I. J., Blake, D. R., and Rowland, F. S.: Measurements of nonmethane hydrocarbons in 28 United States cities, Atmos. Environ., 42, 170-182, 2008.

Bernath, P. F., McElroy, C. T., Abrams, M. C., Boone, C. D., Butler, M., Camy-Peyret, C., Carleer, M., Clerbaux, C., Coheur, P. F., Colin, R., and DeCola, P., DeMazière, M., Drummond, J. R., Dufour, D., Evans, W. F. J., Fast, H., Fussen, D., Gilbert, K., Jennings, D. E., Llewellyn, E. J., Lowe, R. P., Mahieu, E., McConnell, J. C., McHugh, M., McLeod, S. D., Michaud, R., Midwinter, C., Nassar, R., Nichitiu, F., Nowlan, C., Rinsland, C. P., Rochon, Y. J., Rowlands, N., Semeniuk, K., Simon, P., Skelton, R., Sloan, J. J., Soucy, M.-A., Strong, K., Tremblay, P., Turnbull, D., Walker, K. A., Walkty, I., Wardle, D. A., Wehrle, V., Zander, R., and Zou, J.: Atmospheric chemistry experiment (ACE): mission overview, Geophys. Res. Lett., 32, L15S01, https://doi.org/10.1029/2005GL022386, 2005.

Bishop, G. A. and Stedman, D. H.: A Decade of On-road Emissions Measurements, Environ. Sci. Technol., 42, 1651-1656, https://doi.org/10.1021/es702413b, 2008.

Blake, N. J., Blake, D. R, Simpson, I. J., Meinardi, S., Swanson, A. L., Lopez, J. P., Katzenstein, A. S., Barletta, B., Shirai, T., Atlas, E., Sachse, G., Avery, M., Vay, S., Fuelberg, H. E., Kiley, C. M., Kita, K., and Rowland, F. S.: NMHCs and halocarbons in Asian continental outflow during the Transport and Chemical Evolution over the Pacific (TRACE-P) field campaign: Comparison with PEM-West B, J. Geophys. Res., 108, 8806, https://doi.org/10.1029/2002JD003367, 2003.

Clerbaux, C., Boynard, A., Clarisse, L., George, M., Hadji-Lazaro, J., Herbin, H., Hurtmans, D., Pommier, M., Razavi, A., Turquety, S., Wespes, C., and Coheur, P.-F.: Monitoring of atmospheric composition using the thermal infrared IASI/MetOp sounder, Atmos. Chem. Phys., 9, 6041-6054, https://doi.org/10.5194/acp-96041-2009, 2009.

Coheur, P.-F., Herbin, H., Clerbaux, C., Hurtmans, D., Wespes, C., Carleer, M., Turquety, S., Rinsland, C. P., Remedios, J., Hauglustaine, D., Boone, C. D., and Bernath, P. F.: ACE-FTS observation of a young biomass burning plume: first reported measurements of $\mathrm{C}_{2} \mathrm{H}_{4}, \mathrm{C}_{3} \mathrm{H}_{6} \mathrm{O}, \mathrm{H}_{2} \mathrm{CO}$ and PAN by infrared occultation from space, Atmos. Chem. Phys., 7, 5437-5446, https://doi.org/10.5194/acp-7-5437-2007, 2007.

Conley, S., Franco, G., Faloona, I., Blake, D. R., Peischl, J., and Ryerson, T. B.: Methane emissions from the 2015 Aliso Canyon blowout in Los Angeles, CA, Science, 351, 1317-1320, https://doi.org/10.1126/science.aaf2348, 2016.

Dolan, W., Payne, V. H., Kualwik, S. S., and Bowman, K. W.: Satellite observations of ethylene $\left(\mathrm{C}_{2} \mathrm{H}_{4}\right)$ from the Aura Tropospheric Emission Spectrometer: A scoping study, Atmos. Environ., 141, 388-393, 2016. 
Gaffney, J. S., Marley, N. A., and Blake, D. R.: Baseline measurements of ethene in 2002: Implications for increased ethanol use and biomass burning on air quality and ecosystems, Atmos. Environ., 56, 161-168, 2012.

Herbin, H., Hurtmans D., Clarisse L., Turquety S., Clerbaux C., Rinsland C. P., Boone C., Bernath P. F., and Coheur P.-F.: Distributions and seasonal variations of tropospheric ethene $\left(\mathrm{C}_{2} \mathrm{H}_{4}\right)$ from Atmospheric Chemistry Experiment (ACE-FTS) solar occultation spectra, Geophys. Res. Lett., 36, L04801, https://doi.org/10.1029/2008GL036338, 2009.

Hough, A. M.: Development of a two-dimensional global troposphere model: Model chemistry, J. Geophys. Res., 96, 73257362, 1991.

Irion, F. W., Gunson, M. R., Toon, G. C., Chang, A. Y., Eldering, A., Mahieu, E., Manney, G. L., Michelsen, H. A., Moyer, E. J., Newchurch, M. J., Osterman, G. B., Rinsland, C. P., Salawitch, R. J., Sen, B., Yung, Y. L., and Zander, R.: Atmospheric Trace Molecule Spectroscopy (ATMOS) Experiment Version 3 data retrievals, Appl. Opt., 41, 6968-6979, 2002.

Lewis, A. C., Evans, M. J., Hopkins, J. R., Punjabi, S., Read, K. A., Purvis, R. M., Andrews, S. J., Moller, S. J., Carpenter, L. J., Lee, J. D., Rickard, A. R., Palmer, P. I., and Parrington, M.: The influence of biomass burning on the global distribution of selected non-methane organic compounds, Atmos. Chem. Phys., 13, 851-867, https://doi.org/10.5194/acp-13-851-2013, 2013.

Müller, J.-F. and Brasseur, G.: IMAGES: A three-dimensional chemical transport model of the global troposphere, J. Geophys. Res.-Atmos., 100, 16445-16490, 1995.

Olivella, S. and Solé, A.: Unimolecular decomposition of $\beta$ hydroxyethylperoxy radicals in the HO-initiated oxidation of ethene: A theoretical study, J. Phys. Chem. A, 108, 1165111663, 2004.

Paton-Walsh, C., Jones, N. B., Wilson, S. R., Haverd, V., Meier, A., Griffith, D. W. T., and Rinsland, C. P.: Measurements of trace gas emissions from Australian forest fires and correlations with coincident measurements of aerosol optical depth, J. Geophys. Res., 110, D24305, https://doi.org/10.1029/2005JD006202, 2005.

Poisson, N., Kanakidou, M., and Crutzen, P. J.: Impact of NonMethane Hydrocarbons on Tropospheric Chemistry and the Oxidizing Power of the Global Troposphere: 3-Dimensional Modelling Results, J. Atmos. Chem., 36, 157-230, 2000.

Rinsland, C., Paton-Walsh, C., Jones, N. B., Griffith, D. W., Goldman, A., Wood, S., Chiou, L., and Meier, A.: High Spectral resolution solar absorption measurements of ethylene $\left(\mathrm{C}_{2} \mathrm{H}_{4}\right)$ in a forest fire smoke plume using HITRAN parameters: Tropospheric vertical profile retrieval, J. Quant. Spectrosc. Ra., 96, 301-309, 2005.

Rothman, L. S., Barbe, A., Chris Benner, D., Brown, L. R., CamyPeyret, C., Carleer, M. R., Chance, K., Clerbaux, C., Dana, V., Devi, V. M., Fayt, A., Flaud, J.-M., Gamache, R. R., Goldman, A., Jacquemart, D., Jucks, K. W., Lafferty, W. J., Mandin, J.Y., Massie, S. T., Nemtchinov, V., Newnham, D. A., Perrin, A., Rinsland, C. P., Schroeder, J., Smith, K. M., Smith, M. A. H., Tang, K., Toth, R. A., Vander Auwera, J., Varanasi, P., Yoshino, K.,: The HITRAN molecular spectroscopic database: edition of 2000 including updates through 2001, J. Quant. Spectrosc. Ra., $82,5-44,2003$.

Rothman, L. S., Gordon, I. E., Babikov, Y., Barbe, A., Chris Benner, D., Bernath, P. F., Birk, M., Bizzocchi, L., Boudon, V., Brown,
L. R., Campargue, A., Chance, K., Cohen, E. A., Coudert, L. H., Devi, V. M., Drouin, B. J., Fayt, A., Flaud, J.-M., Gamache, R. R., Harrison, J. J., Hartmann, J.-M., Hill, C., Hodges, J. T., Jacquemart, D., Jolly, A., Lamouroux, J., Le Roy, R. J., Li, G., Long, D. A., Lyulin, O. M., Mackie, C. J., Massie, S. T., Mikhailenko, S., Müller, H. S. P., Naumenko, O. V., Nikitin, A. V., Orphal, J., Perevalov, V., Perrin, A., Polovtseva, E. R., Richard, C., Smith, M. A. H., Starikova, E., Sung, K., Tashkun, S., Tennyson, J., Toon, G. C., Tyuterev, V. I. G., and Wagner, G.: The HITRAN2012 Molecular Spectroscopic Database, J. Quant. Spectrosc. Ra., 130, 4-50, 2013.

Sather, M. E. and Cavender, K.: Trends analyses of 30 years of ambient 8 hour ozone and precursor monitoring data in the South Central U.S.: progress and challenges, Environ. Sci. Process Impacts, 18, 819-831, 2016.

Sawada, S. and Totsuka, T.: Natural and anthropogenic sources and fate of atmospheric ethylene, Atmos. Environ., 20, 821-832, https://doi.org/10.1016/0004-6981(86)90266-0, 1986.

Sen, B., Toon, G. C., Blavier, J.-F., Fleming, E. L., and Jackman, C. H.: Balloon-borne observations of mid-latitude fluorine abundance, J. Geophys. Res., 101, 9045-9054, 1996.

Toon, G. C.: The JPL MkIV Interferometer, Opt. Photonics News, 2, 19-21, 1991.

Toon, G. C.: Telluric line list for GGG2014, TCCON data archive, hosted by CaltechDATA, California Institute of Technology, Pasadena, CA, USA, https://doi.org/10.14291/tccon.ggg2014.atm.R0/1221656, 2014a.

Toon, G. C.: Solar line list for GGG2014. TCCON data archive, hosted by CaltechDATA, California Institute of Technology, Pasadena, CA, USA, https://doi.org/10.14291/tccon.ggg2014.solar.R0/1221658, 2014b.

Toon, G. C., Blavier, J.-F., Sen, B., Salawitch, R. J., Osterman, G. B., Notholt, J., Rex, M., McElroy, C. T., and Russell, J. M.: Ground-based observations of Arctic $\mathrm{O}_{3}$ loss during spring and summer 1997, J. Geophys. Res., 104, 26497-26510, https://doi.org/10.1029/1999JD900745, 1999a.

Toon, G. C., Blavier, J.-F., Sen, B., Margitan, J. J., Webster, C. R., May, R. D., Fahey, D. W., Gao, R., Del Negro, L., Proffitt, M., Elkins, J., Romashkin, P. A., Hurst, D. F., Oltmans, S., Atlas, E., Schauffler, S., Flocke, F., Bui, T. P., Stimpfle, R. M., Bonne, G. P., Voss, P. B., and Cohen, R. C.: Comparison of MkIV balloon and ER-2 aircraft profiles of atmospheric trace gases, J. Geophys. Res., 104, 26779-26790, 1999b.

Toon, G. C., Blavier, J.-F., Sung, K., Rothman, L. S., and Gordon, I.: HITRAN spectroscopy evaluation using solar occultation FTIR spectra, J. Quant. Spectrosc. Ra., 182, 324-336, https://doi.org/10.1016/j.jqsrt.2016.05.021, 2016.

Velasco, E., Lamb, B., Westberg, H., Allwine, E., Sosa, G., ArriagaColina, J. L., Jobson, B. T., Alexander, M. L., Prazeller, P., Knighton, W. B., Rogers, T. M., Grutter, M., Herndon, S. C., Kolb, C. E., Zavala, M., de Foy, B., Volkamer, R., Molina, L. T., and Molina, M. J.: Distribution, magnitudes, reactivities, ratios and diurnal patterns of volatile organic compounds in the Valley of Mexico during the MCMA 2002 \& 2003 field campaigns, Atmos. Chem. Phys., 7, 329-353, https://doi.org/10.5194/acp-7329-2007, 2007. 
Velazco, V. A., Toon, G. C., Blavier, J.-F. L., Kleinbohl, A., Manney, G. L., Daffer, W. H., Bernath, P. F., Walker, K. A., and Boone, C.: Validation of the Atmospheric Chemistry Experiment by noncoincident MkIV balloon profiles, J. Geophys. Res., 116, D06306, https://doi.org/10.1029/2010JD014928, 2011.

Warneke, C., McKeen, S. A., De Gouw, J. A., Goldan, P. D., Kuster, W. C., Holloway, J. S., Williams, E. J., Lerner, B., Parrish, D. D., Trainer, M., Fehsenfeld, F. C., Kato, S., Atlas, E. L., Baker, A., and Blake, D. R.: Determination of urban volatile organic compound emission ratios and comparison with an emissions database, J. Geophys. Res.-Atmos., 112, D10S47, https://doi.org/10.1029/2006JD007930, 2007.

Warneke, C., de Gouw, J. A., Holloway, J. S., Peischl, J., Ryerson, T. B., Atlas, E., Blake, D., Trainer, M., and Parrish, D. D.: Multiyear trends in volatile organic compounds in Los Angeles, California: Five decades of decreasing emissions, J. Geophys. Res., 117, D00V17, https://doi.org/10.1029/2012JD017899, 2012.

Washenfelder, R. A., Young, C. J., Brown, S. S., Angevine, W. M., Atlas, E. L., Blake, D. R., Bon, D. M., Cubison, M. J., de Gouw, J. A., Dusanter, S., Flynn, J., Gilman, J. B., Graus, M., Griffith, S., Grossberg, N., Hayes, P. L., Jimenez, J. L., Kuster, W. C., Lefer, B. L., Pollack, I. B., Ryerson, T. B., Stark, H, Stevens, P. S., and Trainer, M. K.: The glyoxal budget and its contribution to organic aerosol for Los Angeles, California, during CalNex 2010, J. Geophys. Res., 116, D00V02, https://doi.org/10.1029/2011JD016314, 2011.

Wofsy, S. C., the HIPPO Science Team, and Cooperating Modellers and Satellite Teams: HIAPER Pole-to-Pole Observations (HIPPO): fine-grained, global-scale measurements of climatically important atmospheric gases and aerosols, Philos. T. R. Soc. A, 369, 2073-2086, https://doi.org/10.1098/rsta.2010.0313, 2011.
Wofsy, S. C., Daube, B. C., Jimenez, R., Kort, E., Pittman, J. V., Park, S., Commane, R., Xiang, B., Santoni, G., Jacob, D., Fisher, J., Pickett-Heaps, C., Wang, H., Wecht, K., Wang, Q.-Q., Stephens, B. B., Shertz, S., Watt, A. S., Romashkin, P., Campos, T., Haggerty, J., Cooper, W. A., Rogers, D., Beaton, S., Hendershot, R., Elkins, J. W., Fahey, D. W., Gao, R. S., Moore, F., Montzka, S. A., Schwarz, J. P., Perring, A. E., Hurst, D., Miller, B. R., Sweeney, C., Oltmans, S., Nance, D., Hintsa, E., Dutton, G., Watts, L. A., Spackman, J. R., Rosenlof, K. H., Ray, E. A., Hall, B., Zondlo, M. A., Diao, M., Keeling, R., Bent, J., Atlas, E. L., Lueb, R., and Mahoney, M. J.: HIPPO Merged 10-second Meteorology, Atmospheric Chemistry, Aerosol Data (R_20121129), Carbon Dioxide Information Analysis Center, Oak Ridge National Laboratory, Oak Ridge, Tennessee, USA, https://doi.org/10.3334/CDIAC/hippo_010 (Release 20121129), 2012.

Wunch, D., Toon, G. C., Blavier, J.-F. L., Washenfelder, R. A., Notholt, J., Connor, B. J., Griffith, D. W. T., Sherlock, V., and Wennberg, P. O.: The total carbon column observing network, Philos. T. R. Soc. A, 369, 2087-2112, https://doi.org/10.1098/rsta.2010.0240, 2011.

Xue, L., Wang, T., Simpson, I. J., Ding, A., Gao, J., Blake, D. R., Wang, X., Wanga, W., Lei, H., and Jin, D.: Vertical distributions of non-methane hydrocarbons and halocarbons in the lower troposphere over northeast China, Atmos. Environ., 45, 6501-6509, 2011. 